\title{
KESEHATAN DAN KESELAMATAN KERJA BAGI PETUGAS KEBERSIHAN DI DINAS KEHUTANAN DAN LINGKUNGAN HIDUP PROVINSI BALI
}

\author{
Kadek Yohanes Septian Adi, I Nyoman Gede Sugiartha, I Putu Gede Seputra \\ Fakultas Hukum, Universitas Warmadewa, Denpasar-Bali, Indonesia \\ yoha11.septia1127@gmail.com, nyomansugiartha14@gmail.com, gamyongputu@gmail.com
}

\begin{abstract}
Abstrak
Resiko dari petugas kebersihan lingkungan sangatlah tinggi mengingat dari pekerjaan yang mereka jalani yang dimana pekerjaannya selalu berhubungan dengan kebersihan sampah yang ada dilingkungan Dinas Kehutanan dan Lingkungan Provinsi Bali. Berkaitan dengan hat tersebut tujuan penelitian ini untuk mengungkap jaminan kesehatan dan keselamatan kerja petugas kebersihan di Dinas Kehutanan Provinsi Bali dan perlindungan hukum pemerintah tentang jaminan pelaksanaan kesehatan dan keselamatan kerja bagi petugas kebersihan di Dinas Kehutanan dan Lingkungan Hidup Provinsi Bali. Metode penelitian ini adalah penelitian hukum empiris. Data primer diperoleh melalui penelitian lapangan, data sekunder diperoleh dari buku-buku, peraturan perundangundangan. Bahan-bahan hukum yang diperoleh kemudian diklasifikasikan dan digabungkan serta dianalisis secara sistematis dan disaj ikan secara deskriptif. Penelitian ini menyimpulkan bahwa, pengaturan mengenai jaminan kesehatan bagi pekerja di lingkungan Dinas Kehutanan Provinsi Bali sudah sesuai dengan peraturan yang ditetapkan oleh Undang-Undang No. 13 Tahun 2003.
\end{abstract}

Kata Kunci: Kesehatan dan Keselamatan Kerja, Perlindungan Hukum, Petugas Kebersihan.

\begin{abstract}
The risk from environmental cleaners is very high considering the work they do, where their work is always related to cleaning the garbage that is within the Bali Provincial Forestry and Environment Service. In this regard, the purpose of this study is to reveal the health and safety insurance for cleaners in the Bali provincial forestry office and the government 's legal protection on guaranteeing the implementation of occupational health and safety for cleaners at the Bali Provincial Forestry and Environment Service. This research method is empirical legal research. Primary data is obtained through field research, secondary data is obtained from books, laws and regulations. The legal materials obtained are then classified and combined as well as analyzed systematically and presented descriptively. This study concludes that the regulation regarding health insurance for workers in the Bali Provincial Forestry Service is in accordance with the regulations stipulated by Law no. 13 Year 2003.
\end{abstract}

Keywords: Occupational Health and Safety, Legal Protection, Janitor.

\section{PENDAHULUAN}

Keselamatan kerja bagi pekerja adalah hal yang sangat penting yang harus diperhatikan dalam dunia maupun perkembangan industri itu sendiri. Secara spesifik keselamatan bagi pekerja telah diperhatikan sejak tahun 1800 an bersamaan dengan revolusi dunia industri itu sendiri, revolusi tersebut ditandai dengan ditemukannya mesin uap yang membawa perubahan dasar bagi dunia industri dalam proses produksi dan hat tersebut terjadi di lnggris (Ramli, 2010).

Perkembangan dunia industri tersebut menimbulkan dampak yang besar terhadap hubungan antar sesama pekerja di tempat bekerjanya. Pekerja tersebut berubah seperti layaknya rnesin yang dimana dapat dengan mudah untuk diganti dengan yang baru. Karena hal tersebut, keselamatan kerja kurang diperhatikan sehingga menimbulkan terjadinya banyak kecelakaan kerja. Perkembangan terhadap pembangunan di Provinsi Bali yang diiringi dengan pertumbuhan penduduk yang semakin pesat, menuntut daerah untuk mewujudkan daerah yang bersih, dalam mewujudkan daerah yang bersih tersebut dibutuhkanlah pelaksana tugas dalam membantu pemerintah dalam upaya mewujudkannya dan perugas tersebut memiliki kebijakan-kebijakan nya sendiri dalam pelaksanaanya.

Tenaga kerja adalah aspek penting guna menunjang pembangunan nasional, oleh karena itu pemerintah rnempunyai kewajiban dalam memberikan perlidungan bagi para tenaga kerja. Peningkatab terhadap kualitas hidup manusia tidak mungkun tercapai jika tidak diiringi dengan 
jaminan hidup yang diberikan oleh pemerintah kepadanya, perlindungan tersebut disesuaikan dengan harkat dan martabat manusia itu sendiri seperti, pemeliharaan dan pengembangan terhadap tenaga kerja, sesuai dengan apa yang dijelaskan dalam Undang-Undang Nomor 1 Tahun 1970 Tentang keselamatan kerja. Salah satu jenis pekerjaan yang seringkali terjadinya kecelakaan dan masalah kesehatan kerja adalah petugas kebersihan, contohnya petugas kebersihan dikarenakan pekerjaan yang mengharuskan mereka berhadapan dengan alat-alat tajam maupun berat (Syarifah Yeti Fakhrina \& Asniar, 2017). Maka dalam hal ini diperlukannya sebuah upaya dalam meminimalisir kecelakaan yang akan terjadi pada saat bekerja (Ardiansah \& Oktapani, 2019).

Perlindungan atas keselamatan bagi pekerja di Dinas Kehutanan dan Lingkungan Hidup di Provinsi Bali merupakan tanggung jawab yang harus diberikan oleh pemerintah kepada pekerja, Perlindungan tersebut diberikan mengingat resiko kerja dari pekerja kebersihan di Dinas Kehutanan dan Lingkungan Hidup Provinsi Bali sangatlah tinggi, mengingat data atas kecelakan yang dialami oleh tenaga kerja dibidang ini sangatlah tinggi, atas dasar tersebutlah perimbangan pemberian perlindungan atas keselamatan tenaga kerja di Dinas ini haruslah diperhatikan secara seksama oleh pemerintah.

Peraturan pemerintah lainnya yang mengatur mengenai perlindungan atas keselarnatan bagi pekerja juga dikaitkan dengan UU No, 3 Tahun 1992 Tentang Jaminan Sosial Bagi Tenaga Kerja. Dalam praktek pemberian jaminan sosial tersebut, tenaga kerja mendapatkan perhatian oleh pemerintah apabila tenaga kerja mengalami kecelakaan kerja, sakit dan kebutuhan atas perlindungan sosial. Atas dasar tersebut petugas kebersihan di Dinas Kehutanan dan Lingkungan Hidup Provinsi Bali berhak atas perlindungan, mengingat Kesehatan dan keselamatan kerja di dinas kebersihan berpengaruh terhadap kinerjanya dalam rnenjaga kebersihan di daerah Provinsi Bali.

Pembangunan dan pemberdayaan tenaga kerja menjadi salah satu tujuan yang diutamakan oleh pemerintah dengan cara memperhatikan kesejahteraan pekerja itu sendiri, sesuai dengan UU No. 13 Tahun 2013 Tentang Ketenagakerjaan yang dimana dalam pasal 4 menyebutkan, memberdayakan tenaga kerja secara optimal dan manusiawi, mewujudkan pemerataan kesempatan kerja dan penyediaan tenaga kerja sesuai dengan kebutuhan dari pembangunan nasional itu sendiri, memberikan rasa aman bagi pekerja dalam melakukan pekerjaanya dan meningkatkan kesejahteraan hidup dari pekerja.

Diberikannya perlindungan yang bersifat jaminan atas kesetaraan bagi pekerja atau petugas kebersihan di Dinas Kehutanan dan Lingkungan Hidup Provinsi Bali, pada dasarnya mengacu pada VU NO. 13 Tahun 2013 yang dimana mengarur tentang Kesehatan dan keselamatan kerja. Perlindungan terhadap tenaga kerja juga didukung oleh Peraturan Presiden No. 109 Tahun 2013 yang mengatur tentang penahapan atas jaminan sosial. Peningkatan terhadap kualitas hidup manusia akan sulit dan bahkan tidak akan tercapai jika tidak diberikan perlindungan atas Kesehatan dan keselamatan kerja, pemberian perlindungan tersebut bertujuan untuk memberikan ketenangan bagi pekerja dan memberikan rasa aman atas kesejahteraan pekerja. Dalam perlindungan tersebut terdapat beberapa hak yang akan diperoleh oleh tenaga kerja, yaitu: kesehatan dan keselarnatan bagi pekerja, moral dan kesusilaan, perlakuan yang baik bagi setiap pekerja sesuai dengan norrna-norma yang berlaku dimasyarakat dan sesuai dengan harkat martabat manusia pada umumnya.

Perlindungan dalam kesehatan bagi pekerja atau buruh dengan tujuan untuk mewujudkan produktivitas kerja yang maksimal diselenggarakan upaya Kesehatan yang dilaksanakan sesuai dengan ketentuan peraturan perundang-undangan yang mengaturnya (Husni, 2003). Jaminan sosial bagi tenaga kerja dimaksudkan agar dapat memberikan perlindungan bagi tenaga kerja atas resiko sosial dan ekonomi yang dapat ditimbulkan oleh pekerjaannya, baik itu berupa kecelakaan kerja, sakit dan meninggal dunia. Dengan adanya jaminan sosial tersebut diharapkan agar dapat memberikan ketenangan bagi tenaga kerja sehingga dapat menunjang produktivitasnya.

Menurut Yuantari \& Nadia (2018) pada dasarnya perlindungan hukum bagi setiap tenaga kerja telah tertera pada Undang-Undang No. 1 Tahun 1970 yang menyatakan bahwa setiap tenaga kerja memiliki hak untuk mendapat perlindungan keselamatan dalam melakukan pekerjaan untuk kesejahteraan hidup dan meningkatkan produksi serta produktivitas Nasional. Keselamatan dan Kesehatan Kerja (K3) tidak hanya tanggung jawab dari satu pihak melainkan tanggung jawab mulai dari pimpinan tertinggi hingga karyawan. Semua pihak harus sama-sama menyadari arti pentingnya Keselamatan dan Kesehatan Kerja (Patrisia, 2018). Lebih lanjut, tenaga kerja wajib diberikan jaminan keselamatan dengan melakukan tindakan pencegahan terjadinya kecelakaan dan penyakit 
yang disebabkan pekerjaan, mengurangi atau mengendalikan efek negatif ditempat kerja, pengobatan atau rehabilitasi serta penyuluhan kesehatan (Ferial, 2020).

Maka berdasarkan penjelasan diatas dapat dirumuskan tujuan penelitian ini untuk mengungkap jaminan kesehatan dan keselamatan kerja petugas kebersihan di Dinas Kehutanan Provinsi Bali dan perlindungan hukum pemerintah tentang jaminan pelaksanaan kesehatan dan keselamatan kerja bagi petugas kebersihan di Dinas Kehutanan dan Lingkungan Hidup Provinsi Bali

\section{METODE PENELITIAN}

Penelitian ini menggunakan metode penelitian hukum empiris, yang dirnana pengkajian dilakukan secara mengimplementasikan pengaturan-pengaturan hukum seperti Undang-Undangan dan peraturan lainnya secara nyata pada setiap peristiwa hukum yang terjadi ditengah kehidupan masyarakat. Pendekatan masalah dalam penelitian hukum ini dilakukan dengan cara penerapan atau pengimplementasian dari ketentuan-ketentuan hukum pada suaru peristiwa (Abdul Kadir, 2015). Teknik pengurnpulan bahan hukum yang digunakan adalah: bahan hukum primer didapat dengan melakukan penelitian secara langsung dilapangan yang sumber informasinya didapat melalui informan yang merniliki kompetensi yang sesuai dengan tema penuJisan ini, Bahan hukum sekunder diperoleh melalui undang-undang, pengaturan hukum yang memiliki keterkaitan atas penulisan ini dan beberapa buku-buku serta literatur yang memiliki keterkaitan dengan tema penulisan. Bahan hukum tersier didapat melalui kamus Bahasa Indonesia, Kamus Bahasa Belanda dan encyclopedia. Bahan-bahan hukum yang diperoleh kemudian diklasifikasikan dan digabungkan serta dianalisis secara sistematis dan disaj ikan secara deskriptif analitis. Sehingga menjadikan substansi dalam tulisan ini sesuai atau selaras dengan aturan-aturan atau sumber hukum, doktrin-doktrin yang dijadikan sebagai acuan dan sesuai dengan pendapat narasumber mengenai tema penulisan ini.

\section{HASIL DAN PEMBAHASAN}

\section{Jaminan Kesehatan dan Keselamatan Kerja Petugas Kebersihan di Dinas Kehutanan Provinsi Bali}

Undang-Undang Nomor 13 Tahun 2013 yang didalamnya menyatakan bahwa penerapan dari segaJa saran dan upaya untuk mencegah kecelakaan kerja, dalam hal ini keselamatan yang dimaksud adalah yang berkaitan dengan mesin, alat kerja yang berlandaskan tempat kerja dan lingkungan kerja dari pekerja itu sendiri. Tujuan dari keselamatan kerja itu sendiri adaJah untuk melindungi keselarnatan bagi pekerja dalam melaksanakan tugasnya, melindungi keselamatan bagi setiap pekerja yang berada di dalarn lokasi tempatnya bekerja dan memberikan keamanan bagi pekerja dalam bentuk peralatan bekerja dan alat produksi agar dapat digunakan secara efisien.

Keselamatan kerja adalah keselamatan bagi pekerja saat bekerja dengan berkaitan dengan mesin, alat kerja, bahan dan proses pengolahannya, tempat bekerja, lingkungan dan cara dalam bekerja (Suma'mur, 2009). Terjadinya kecelakaan kerja dapat dicegah dengan cara bekerja dengan teliti, fokus dan secara terorganisir sesuai dengan prosedur kerja. Aturan yang dijadikan acuan atau diterapkan oleh dinas tenaga kerja mengacu pada peraturan perundang-undangan yang sudah ada sebelumnya. Seperti yang telah dijelaskan dalam UU No. 13 Tahun 2003 Tentang Ketenagakerjaan pada pasal 86 dan 87 yang menyatakan setiap pekerja berhak atas perlindungan moral, perlakuan yang sesuai dengan hak asasi manusia dan sesuai dengan norma-norma kesopanan dalam masyarakat, mementingkan keselamatan pekerja guna mewujudkan efektivitas produksi, penerapan sistem rnanajemen Kesehatan kerja yang terintegrasi dengan sistem manajemen dari perusahaan.

Upaya dalam melindungi keselamatan pekerja dengan tujuan untuk meningkatkan produktivitas produksi oleh pekerja dilakukanlah upaya keselamatan dan Kesehatan kerja (Mangkunegara, 2020). Upaya tersebut dapat terwujud dengan cara melakukan pembinaan di bidang norma ketenagakerjaan. Yang dimaksud dengan norma ketenagakerjaan adalah pernbenrukan, pengawasan norma pekerja. Yang bertanggung jawab atas keselamatan dan keamanan pekerja adalah pimpinan atau pengurus dari perusahaan tempat si pekerja itu bekerja. Kewajiban dari pimpinan perusahaan tersebut adalah meminimalisir kondisi atau bahaya yang dapat ditimbulkan di tempat kerja, menyediakan alat perlindungan bagi pekerja sesuai dengan ketentuan dan prosedumya, cara dan sistem dalam bekerja dan melakukan pemeriksaan rutin baik Kesehatan fisik dan mental dari pekerja. 
Dalam merealisasikan Kesehatan bagi pekerja memerlukan sinergi dari beberapa elemen yaitu pemerintah, perusahaan dan pekerja. Bentuk partisipasi dalam merealisasikan Kesehatan tersebut dapat berupa partisipasi secara langsung oleh panitia melalui pembinaan kesehatan dan keselamatan kerja oleh perusahaan dan partisipasi berupa kesetiakawanan merupakan bagian dari sarana untuk mewujudkan efisiensi kerja bagi pekerja.

Jamsostek juga merupakan upaya pemerintah dalam memberikan perlindungan keselamatan kerja bagi pekerja, Jamsostek adalah perlindungan bagi pekerja yang diberikan dalam bentuk santunan berupa uang tunai sebagai pengganti dari penghasilan yang hilang yang diakibatkan oleh keadaan dari tenaga kerja berupa kecelakaan saat bekerja, sakit, ha mil atau meninggal dunia. Program yang terkandung dalamjaminan sosial sesuai dengan yang terkandung didalam UU NO. 3 Thn 1992 adalah jaminan atas terjadinya kecelakaan kerja,jaminan atas kematian, jaminan hari tua bagi pekerja atau jaminan pensiun dan jaminan Kesehatan bagi pekerja. Atas dasar tersebut maka jangkauan atas jaminan sosial bagi tenaga kerja sangatlah luas.

Kecelakaan kerja adalah kecelakaan yang timbul saat bekerja. Kecelakaan kerja dapat terjadi dikarenakan ketidak hati-hatian dari pekerja itu sendiri dan juga dapat terjadi dari kelalaian perusahaan dalam menjaga keamanan pekerja selama melakukan pekerjaan. Terjadinya kecelakaan saat bekerja akan atau menuju ternpat kerja juga dapat dikategorikan sebagai kecelakaan kerja. Kecelakaan kerja itu sendiri dapat dibagi kedalam dua kategori, yaitu kecelakaan kerja industri dan kecelakaan perjalanan. Kecelakaan industri adalah kecelakaan kerja yang terjadi kepada pekerja di tempat bekerja karena adanya sesuatu yang membahayakan keselamatan pekerja dan kecelakaan perjalanan adalah kecelakaan yang timbul selama perjalanan pekerja ke tempatnya bekerja.

\section{Perlindungan Hukum Pemerintah Tentang Jaminan Pelaksanaan Kesehatan dan Keselamatan Kerja bagi Petugas Kebersihan di Dinas Kehutanan dan Lingkungan Hidup Provinsi Bali}

Upaya pencegahan terjadinya kecelakaan kerja merupakan prioritas dari pemerintah dalam upaya melindungi dan memberikan kenyamanan bagi pekerja melalui perusahaan. Turun nya akan kecelakaan kerja dari suatu perusahaan mengakibatkan terjadinya peningkatan produktivitas dan juga memberikan rasa aman dan nyaman bagi pekerja itu sendiri. Aturan yang dijadikan acuan atau diterapkan oleh dinas tenaga kerja mengacu pada peraturan perundang-undangan yang sudah ada sebelumnya. Seperti yang telah dijelaskan dalam UU No. 13 Tahun 2003 Tentang Ketenagakerjaan pada pasal 86 dan 87 yang menyatakan setiap pekerja berhak atas perlindungan moral, perlakuan yang sesuai dengan hak asasi manusia dan sesuai dengan norma-norma kesopanan dalam masyarakat, mementingkan keselamatan pekerja guna mewujudkan efektivitas produksi, penerapan sistem manajemen Kesehatan kerja yang terintegrasi dengan sistem manajemen dari perusahaan.

Perusahaan atau tempat kerja adalah setiap ternpat yang merniliki suatu usaha baik itu yang menyediakan barang ataupun jasa, adanya sumber yang kemungkinan menimbulkan bahaya selama proses bekerja, adanya tenaga kerja yang terlibat didalamnya dan dilakukan secara terus menerus maupun hanya dalam waktu tertentu. Petugas kebersihan kota Denpasar adalah salah satu profesi yang cukup penting dalam upaya menjaga kebersihan kota Denpasar, namun seringkali profesi ini tidak diperhatikan atau cenderung diabaikan oleh pemerintah. Profesi yang sering diabaikan ini, seharusnya petugas kebersihan ini diperhatikan lebih baik oleh pemerintah, baik itu dalam pemberian fasilitas bekerja dan perlindungan atas jarninan Kesehatan bagi pekerja.

Peneliti mengadakan Wawancara dengan Bapak Ida Bagus Krisna Jaya, Kepala Seksi Monitoring dan Pelaporan di Dinas Kehutan dan Lingkungan Hidup Provinsi Bali pada tanggal 4 Januari 2021 menerangkan bahwa di lingkungan Dinas Kehutanan dan Lingkungan Hidup Provinsi Bali terdapat 301 orang jumlah pegawai yang terdiri dari 229 orang Pegawai Negeri Sipil dan 103 Pegawai Kontrak termasuk didalamnya Petugas Kebersihan. Disamping itu terdapat 1.800 orang tenaga kebersihan yang juga berada dibawah Dinas Kehutanan dan Lingkungan Hidup Provinsi Bali, dengan sistern kerja dengan batasan wilayah kerja sekitar 1 kilometer dan perugas dibagi dalam 2 shift yaitu shift pagi dimulai dari Pukul 07.30 sampai dengan 12.00. dan untuk shift petugas sore dimulai dari pukul 13.00 s.d. 15.00 wita, dengan gaji setiap bulannya Rp.2.714.000,. ( Dua juta tujuh ratus empat belas ribu rupiah), untuk Petugas Kebersihan mempunyai Batasan umur yaitu sampai dengan umur 58 (lima puluh delapan) tahun dengan catatan masih mampu dan bias untuk bertugas sebagai tukang sapu dan pekerjaan kebersihan lainnya seperti memotong rurnput dan merawat taman 
yang ada di bawah tanggung jawab dinas kehutanan dan Lingkungan Hidup Provinsi Bali.

\section{SIMPULAN DAN SARAN \\ 1. Simpulan}

Dapat disimpulkan bahwa, pengaruran atas jaminan Kesehatan dan keselamatan bagi pekerja telah diatur dalam UU No.13 Thn 2003 Tentang ketenagakerjaan. Dalam Undang-Undang tersebut terutama dalam pasal 85 dan 86 yang di dalarnnya telah memaparkan mengenai hak bagi pekerja yang harus dipenuhi oleh pihak perusahaan, baik itu hak atas perlindungan Kesehatan, mental maupun moril dari pekerja. Dan pada pasal 87 juga menjelaskan mengenai sistem manajemen atas Kesehatan dan keselamatan kerja merupakan tanggung jawab bagi perusahaan. Adapun perlindungan hukum pemerintah perihal pemberian jaminan Kesehatan dan keselamatan kerja bagi pekerja di Dinas Kehutanan dan Lingkungan Hidup Provinsi Bali telah sesuai dengan Undang-Undang No. 13 Tahun 2003 yang didalamnya mengatur tentang ketenagakerjaan. Dimana pemerintah Provinsi memperhatikan keselamatan para pekerjanya dan pemerintah juga bertujuan untuk memberikan rasa aman bagi pekerja dengan menerapkan segala ketentuan yang tercantum dalam UU yang mengatur mengenai ketenagakerjaan dan jaminan sosialnya.

\section{Saran}

Diharapkan agar pemerintah benar-benar menerapkan apa yang terruang dalam Undang-Undang ketenagakerjaan, dimana pemerintah harus mengawasi baik itu pengusaha maupun pihak pemerintah itu sendiri dalam memberikan hak-hak bagi para pekerja, baik itu berupajaminan Kesehatan, moril dan tunjangan pensiun bagi pekerja. Perwujudan atas jaminan Kesehatan bagi para pekerja di Dinas Kehutanan dan Lingkungan Hidup Provinsi Bali dapat dilakukan dengan melakukan pengecekan Kesehatan rutin bagi pekerja. Diharapkan agar pemerintah menjamin keamanan pekerja di Dinas Kehutanan dan Lingkungan Hidup Provinsi Bali dalam melakukan pekerjaannya dengan memberikan alat-alat yang dapat menunjang keselamatan pekerja selama melakukan pekerjaannya. Alat-alat tersebut dapat berupa, masker, sarung tangan, sepatu dan beberapa alat pelindung diri lainnya. Dan para pekerja juga diharapkan bekerja dengan baik sesuai dengan SOP yang telah diberikan agar terhindar dari kecelakaan kerja.

\section{DAFTAR PUSTAKA}

Abdul Kadir, M. (2015). Hukum Dan Penelitian Hukum. In Bandung: PT. Citra Aditya Bakti. (Vol. 8, Issue 1). PT. Citra Aditya Bakti, Bandung.

Ardiansih, \& Oktapani, S. (2019). Perlindungan Hukum Terhadap Keselamatan Kerja Petugas Kebersihan Kota Pekanbaru. Al Daulah: Jurnal Hukum Pidana Dan Ketatanegaraan, 8(2), 154.

Ferial, R. M. (2020). Penerapan Keselamatan Dan Kesehatan Kerja (K3) Dalam Upaya Pencegahan Penyebaran Virus Covid-19 Pada Area Kerja Pt. Semen Padang. JESS (Journal of Education on Social Science), 4(2), 271.

Husni, L. (2003). Pengantar Hukum Ketenagakerjaan Indonesia. Raja Grafindo Persada, Jakarta. Mangkunegara. (2020). Manajemen Sumber Daya Manusia. Alphabeta, Jakarta.

Patrisia, Y. (2018). Pengaruh Beban Kerja, Kelelahan Kerja Terhadap Kesehatan dan Keselamatan Kerja (K3) Pada Karyawan PT. Kaltim Diamond Coal (KDC). Psikoborneo, 6(1), 183-198.

Ramli, S. (2010). Sistem Manajemen Keselamatan don Kesehatan Kerja. Dian Rakyat, Jakarta.

Suma'mur. (2009). Keselamatan Kerja dan Pencegahan Kecelakaan, Penerbit Sagung Seto Jakarta. Haji Masagung, Jakarta.

Syarifah Yeti Fakhrina, \& Asniar. (2017). Keselamatan Dan Kesehatan Kerja Pada Petugas Kebersihan Di Kota Banda Aceh. Jurnal Ilmiah Mahasiswa Fakultas Keperawatan, 2(3), 1-8.

Yuantari, C., \& Nadia, H. (2018). Analis Resiko Keselamatan dan Kesehatan Kerja Pada Petugas Kebersihan di Rumah Sakit. Faletehan Health Journal, 5(3), 107-116. 